\title{
REVOLUTIONIZE EDUCATION WITH NEW TECHNOLOGY
}

\author{
Bhupinderjit Kaur
}

Assistant Professor

S.G.T.B.College of Education, Khankot, Amritsar

\section{Council for Innovative Research}

\author{
Peer Review Research Publishing System
}

Journal: INTERNATIONAL JOURNAL OF RESEARCH IN EDUCATION METHODOLOGY

Vol 6, No. 1

ijremeditor@gmail.com

www.ijrem.com

\section{ABSTRACT}

New web-based technologies are becoming part and parcel of our education system. If the education system needs to be qualitative, it should be continuously be in track with the contemporary changes in the development of the society. Therefore the programs for continous professional development of teachers should be considered more important than their initial training.

\section{Indexing terms/Keywords}

Revolutionize,Web-based technology,Continous Professional Development,Technophobe

\section{Academic Discipline}

Education

\section{Type(Method/Approach)}

Article

Technology has revolutionized our society. In the last two decades, technology has dramatically penetrated into almost all walks of life and education was not an exception to it. The task of educating the young persons and students is not easy to perform. It needs large numbers of schools, colleges, universities and different kind of educational institutions, lots funds and many other things. Universalization of elementary education is a cherished goal before our nation. Same is the case with our secondary education. In the age of globalization, our educational institutes need to be overhauled. New webbased technologies are becoming part and parcel of our education system. If the education needs to be qualitative, it should continuously be in track with the contemporary changes in the developments in the society.

Technology had crept into our classrooms many years ago in the form of using improvised teaching aids. Various techniques, methods and approaches are used to make the teaching learning process more interesting, more effective, goal-oriented, need based, self-paced and different from routine ways of functioning. There is a dramatic shift from the pen to the keyboard, from blackboard presentation to power-point presentation, from paper pen test to computer based test, from interpersonal instruction to mediated instruction from teacher dependent learning to independent learning. Due to this reason, the present educational system is looking highly different from what it was seen in the past especially with regard to application of technology.

Educational systems around the world are under increasing pressure to use innovative methodologies and integrate new information and communication technology (ICT) in the teaching-learning process in the $21^{\text {st }}$ century. ICT embodies a full range of old and new technologies such as e-mail, internet services, telephone, fax, scanner, printer, computer, laptop, television, mobile etc. Technological devices act as a supplement for the teacher. Through the use of technology teachers can provide opportunities for the students to learn, think critically and discuss among peers supported by ICT. Teacher can take advantage of different kind of information available on internet and can exchange ideas using these with students. Hence, it is essential to utilize the advantages that the technological developments in our teaching learning process present to us. 
The government has launched "New Education Policy" which has adopted the concept of providing distance education to the door steps of all students. With electronic gadgets and equipments it would now become possible for all to learn irrespective of where they are living or working. The communication technology has made the task of taking education to the door steps of students very easy. The leading universities in our country have also made use of these facilities, technologies and gadgets on a large scale. This technology has enabled the learner to learn anything, at anytime and from anywhere. Time and place would not be constraints. Learners can learn at their own-pace. With emerging new technologies, the teaching profession has shifted now from an emphasis on teacher-centered lecture: based instruction to student-centered: interactive learning environment.

With the process of globalization occurring at a fast pace and availability of information in nanoseconds through e-media, the world has shrunk. Internet becomes the gateway of knowledge and also acts as a superhighway in knowledge transaction. Internet has changed the way, we work. Be it any profession, trade, crafts, business and education. It helps in implementing the principle of lifelong learning. It provides opportunities to teachers and students to obtain information regarding any subject with very little effort. It gives every learner a free and friendly access to the resources of media at anytime, anywhere. It encourages independent self learning. Internet is creating a professional bond between teachers as well as educators and administers never seen before in the history of education. It allows teachers to exchange lessons plans and discuss instructional methods with peers around the globe. The internet has created electronically a professional fraternity among teachers. Everybody finds it easier to refer the internet than searching for knowledge and information in fat reference books.

Nowdays the teacher and students obtain much of the information from the World Wide Web (www.com). One of the technological developments is the blog which is often referred to as a second generation web that can be effectively utilized in teaching learning. The term blog is a blend of the terms web and log, leading to web log, weblog and finally blog. It is a website in which items are posted and displayed with the newest at the top. Blogs are usually maintained by an individual with regular entries of commentary, descriptions of events or other materials such as text, images, audio, video, animation and graphics. Since it is a social net work, blogs are interactive, allowing visitors to leave comments and even message each other. The uses of blogs have become popular in educational institutions including public schools and colleges. There are many teacher related blogs on the internet where teachers can share information with one another. In this way the blog often acts as a support system for teachers where they can access ideas, tools, gain support and recognition from other professionals in their field. Some of these blogs have become nationally recognized as useful tools, especially teacher blogs which are directly making a difference in the educational system. It has also been found that blogs can be used to promote writing skills of students in different societies. Teachers also use blogs as a way to post information such as homework, important dates, missed lessons, projects, discussions and other useful classroom information that is accessible by all students and they can access this information from home or from any computer that is connected to the internet.

Therefore, the programs for continued professional development of teachers are considered more important than their initial training programs. The existing system of teacher education program is conventional and unresponsive in the face of recent social, economic and political and technological advances particularly the challenges posed by information and communication technologies, globalization and growing rate of knowledge obsolescence. In the present globalised era, teacher education programs are facing more challenges to maintain the highest possible standard in all aspects like planning, integration of latest technology available, training of teachers in handling those technologies, enhancing professional competency among teacher educators, language skills, teaching commitment, pre-service and in-service programs. Authorities should try to give training to teacher and students on how to access internet for educational purposes, and motivate them to use it in daily teaching-learning process. Learning internet skills must be given the first priority to make tomorrow's workforce competitive in an increasingly high-tech world. It is also important for teachers and their organization to maintain their professional connections with overseas: international and global teacher organization. These organizations enable teachers and teacher educators to have access to advice and expertise which are not available locally.

Training provides certain skills; but whether to utilize these skills or not depends on the attitude of the concerned teacher. Many teachers who received their training or formal education prior to the development of digital age have incorporated advanced technologies into their personal lives but they maintain a sense of resistance to use the same advances in their professional lives. For instance, ATM machines and cell phone with advance technology. The same teacher however, may be prone to resistance in the use of education related technological advances. Teachers who are reluctant users of information and communication technology (ICT) are often labeled as being "technophobe", or too traditional in their teaching style. They revolt against the modern technology because of their beliefs on that these technologies are threatening to their ways of classroom teaching-learning process.

The failure of institutions to embrace ICT and relegation of use of technologies to the periphery of institutional life is placed directly on these technophobic teachers. It is a big challenge to educate these teachers who have a negative mind set against these technologies. It is only through effective teacher education programs, we shall get all the answers to those challenges, curiosities and queries of the future generation because it is the teacher who is to train and shape the potential citizen of tomorrow who in turn participate in the global race.

\section{REFERENCES}

1. P.Vimalkumar,P.Sivakumar( February,2013):Blog-Based Learning An Innovative Approach, Vol.12-no.6, , Edutrack.

2. Patil.S.V(February,2014):Revolutionise Higher Education With Use of ICT, ,52(06) 10-16, Universities News 
3. Priya Pathak, Swati Gupta( Dec,2012): Empowering Women's Participation in ICT: Role of Universities,Vol.10-no.4, Edutrack.

4. Madhu Dr. (Feburary,2012):Technology Cannot Replace a Teacher,Vol.11-no.6,Edutrack 